\title{
Role of public-private partnerships in achieving UNAIDS HIV treatment targets
}

\author{
Ritu Shrivastava ${ }^{1}$, Peter N. Fonjungo ${ }^{1 *}$, Yenew Kebede ${ }^{2}$, Rajendra Bhimaraj ${ }^{3}$, Shabnam Zavahir ${ }^{3}$, Christina Mwangi ${ }^{4}$,
} Renuka Gadde ${ }^{5}$, Heather Alexander ${ }^{1}$, Patricia L. Riley ${ }^{1}$, Andrea Kim $^{1}$ and John N. Nkengasong ${ }^{6}$

\begin{abstract}
Background: Despite progress towards achieving UNAIDS 90-90-90 goals, barriers persist in laboratory systems in sub-Saharan Africa (SSA) restricting scale up of early infant diagnosis (EID) and viral load (VL) test monitoring of patients on antiretroviral therapy. If these facilities and system challenges persist, they may undermine recorded gains and appropriate management of patients. The aim of this review is to identify Public Private Partnerships (PPP) in SSA that have resolved systemic barriers within the VL and EID treatment cascade and demonstrated impact in the scale up of $V L$ and EID.

Methods: We queried five HIV and TB laboratory databases from 2007 to 2017 for studies related to laboratory system strengthening and PPP. We identified, screened and included PPPs that demonstrated evidence in alleviating known system level barriers to scale up national VL and EID testing programs. PPPs that improved associated systems from the point of viral load test request to the use of the test result for patient management were deemed eligible.

Results: We identified six PPPs collaborations with multiple activities in select countries that are contributing to address challenges to scale up national viral load programs. One of the six PPPs reached 14.5 million patients in remote communities and transported up to 400,000 specimens in a year. Another PPP enabled an unprecedented $94 \%$ of specimens to reach national laboratory through improved sample referral network and enabled a cost savings of $62 \%$. Also PPPs reduced cost of reagents and enabled 300,000 tested infants to be enrolled in care as well as reduced turnaround time of reporting results by $50 \%$.

Conclusions: Our review identified the benefits, enabling factors, and associated challenges for public and private sectors to engage in PPPs. PPP contributions to laboratory systems strengthening are a model and present opportunities that can be leveraged to strengthen systems to achieve the UNAIDS 90-90-90 treatment targets for HIV/AIDS. Despite growing emphasis on engaging the private sector as a critical partner to address global disease burden, PPPs that specifically strengthen laboratories, the cornerstone of public health programs, remain largely untapped.
\end{abstract}

Keywords: Public-private partnership, Viral load, Early infant diagnosis, Laboratory systems strengthening, Cascade

\footnotetext{
* Correspondence: pdf4@cdc.gov

'International Laboratory Branch, Division of Global HIV/AIDS, Center for

Global Health, Centers for Disease Control and Prevention, 1600 Clifton Road

NE, Atlanta, GA 30333, USA

Full list of author information is available at the end of the article
}

(c) The Author(s). 2019 Open Access This article is distributed under the terms of the Creative Commons Attribution 4.0 International License (http://creativecommons.org/licenses/by/4.0/), which permits unrestricted use, distribution, and reproduction in any medium, provided you give appropriate credit to the original author(s) and the source, provide a link to the Creative Commons license, and indicate if changes were made. The Creative Commons Public Domain Dedication waiver (http://creativecommons.org/publicdomain/zero/1.0/) applies to the data made available in this article, unless otherwise stated. 


\section{Background}

The Joint United Nations Programme on HIV/AIDS (UNAIDS) fast track treatment targets call for $90 \%$ of people living with HIV infection to know their status; $90 \%$ of those who know their status to receive antiretroviral therapy (ART); and $90 \%$ of those on ART to achieve viral suppression by 2020 [1]. Despite significant progress towards controlling the HIV/AIDS pandemic [2], these new targets have overwhelmed many public health laboratory systems in sub-Saharan Africa (SSA) due to increased demand for early Infant diagnostic (EID) testing of HIV-exposed infants (HEI) and viral load (VL) test monitoring of patients on ART [3]. The $\mathrm{VL}$ and EID cascade is characterized by phases from the point of test request to the use of the test results for patient management. There are three phases and include the pre-analytical phase defined as the period from collection of specimens at the referral clinic to receipt of specimens in the laboratory (includes demand creation for testing from care providers and patients, specimen collection and processing, specimen transport system), the analytical phase defined as the period from testing of specimens to obtaining results at the laboratory (includes quality laboratory testing and supply chain management for test reagents and supplies), and the post-analytical phase which entails results transmission from laboratory to receipt of results at the referral clinic and use for patient management (comprised of result reporting to clinics, interpretation and uptake for patient management). Monitoring and evaluation (M\&E) is cross-cutting through the different phases and allows monitoring of progress of these phases.

Multiple barriers within the VL and EID cascade prevent optimal access and uptake of test results for better patient management. In the pre-analytical phase, these barriers include lack of patient awareness for available HIV test; non-standardized specimen collection practices, and weak specimen referral networks [4]. In the analytical phase, challenges include frequent equipment breakdown, weak supply chain systems, and unsafe biological waste management. In the post analytical phase, the challenges experienced comprise delayed and inconsistent delivery of test results, limited data systems for reporting results, and poor clinician utilization of laboratory results for improved patient management. There is also a dearth of adequate numbers of competent workforce along all phases of the cascade [4-6].

In 2009 leaders of the US Government's global AIDS program stated that "The problems we face today will be solved not by governments alone but in partnerships; partnerships with philanthropy, global business and civil societies" [2]. While global PPPs that have improved public health programs such as Global Fund, Foundation for Innovative New Diagnostics, and the Global Alliance for Vaccines and Immunizations (GAVI), have been around for decades [7], PPPs that specifically target the advancement of laboratories, an indispensable component of these programs, are rare. The gap persist despite the increasing emphasis on engaging the private sector as a critical partner to improve services and systems to address diseases that are threats to public health [811]. One of the reasons for engagement of fewer than anticipated private entities could be the paucity of empirical data and strategies for effective private sector engagement [12].

Studies suggests that the influx of donor funding has led to decreased private contributions for HIV/AIDS. The reduction in private sector investment and engagement raises concerns about the sustainability of HIV/ AIDS programs, particularly in light of the current global economic crisis and emerging competing priorities [13]. There exist opportunities for partnerships to strengthen systems in the VL and EID cascade and address gaps to accelerate achieving the UNAIDS 9090-90 goals. SSA countries are at different stages of scaling up VL and EID and have varying challenges [5]. Partnerships, especially PPP can play an important role in resolving system barriers affecting VL and EID. In this review, we identify and provide a description of PPPs in SSA that have been used to resolve systemic barriers within the cascade and demonstrated its impact in the scale up of VL and EID.

\section{Methods}

\section{Data sources and search strategy}

We queried five HIV and TB laboratory databases (Medline, Embase, CINAHL, Global Health, Scopus) from 2007 to 2017, with an aim to identify public-private partnerships focused on laboratory system strengthening. We used search terms Public -Private Sector Partnerships, private public partnership, public private partnership, laboratory or specimen handling, specimen transport, specimen referral, sample transport, laboratory quality management, laboratory worker or laboratory technician. Only articles published in English were included.

\section{Selection criteria}

We used barriers to scale up VL and EID testing cascade (Fig. 1) as criteria to guide the selection of PPPs in our review. Records of PPPs that were operational in SSA and had successfully implemented interventions to improve systems for demand creation for tests, specimen collection and transportation, laboratory testing, reporting laboratory results to clinics were deemed eligible.

A wide spectrum of private sector engagement options exist for delivery of public health programs [14, 15]. PEPFAR defines PPPs as a 'collaborative endeavors that 


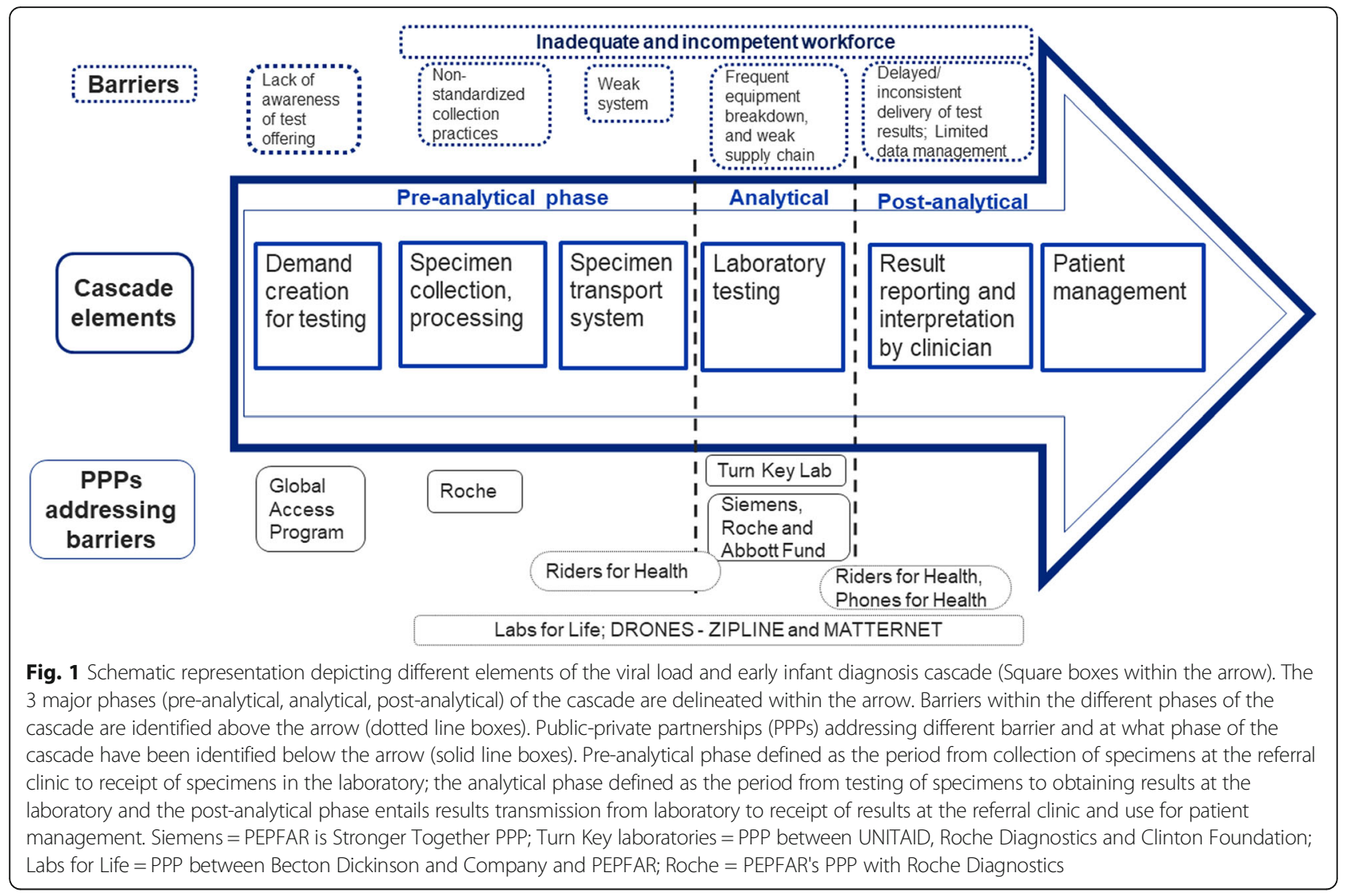

combines monetary and in-kind resources from the public and private sector to accomplish PEPFAR's HIV/ AIDS prevention, care, and treatment goals' [16]. All forms of PPP engagements were included in the identification step (Fig. 2).

\section{Outcomes of interest and data abstraction strategy}

Our search yielded 375 records in EndNoteX7 library, and eight from non-peer reviewed sources bringing our total to 383 records (Fig. 2). Using Endnote's "find duplicates" function we removed 128 duplicates. We systematically assessed each record by evaluating the following broad questions: 1) Was there a clear study objective that addressed barriers to scale up VL and EID testing in record? 2) Did the study use the right methods to address the study objective? 3) Are the results of the study valid? 4) Are the results applicable to my population of interest? Of the 255 remaining articles, 225 records were removed because of their focus on non-healthcare PPPs. We tabulated characteristics of the remaining 30 PPPs by ability of the PPP to address barriers in the various phases of VL and EID cascade, country of operation, name of PPP, start year, intervention type, impact and source using MS Office Excel spreadsheet. Eleven of the 30 abstracts unrelated to laboratory system strengthening were excluded and leaving 19 full text articles for review. Thirteen of the 19 articles provided valuable insights into various modes and interpretations of operationalizing PPPs, benefits and challenges, enabling factors, reasons for dearth of PPPs in global health care. We referenced these 13 articles in introduction and other sections in the manuscript. Six PPP records that met the eligibility criteria were reviewed and analyzed.

\section{Results \\ Pioneering PPPs focused on laboratory system strengthening}

Five of the six eligible PPPs have an international scope and the other one is an example of a local PPP. Three of the six PPPs have partnerships with the President's Emergency Plan for AIDS Relief (PEPFAR) program and the other two are independent of PEPFAR (Table 1).

Memoranda of Understanding (MOUs) were signed between PEPFAR and three private companies to focus on strengthening laboratory networks and systems to support ART scale up. The MOUs were signed between the US Centers for Disease Control and Prevention (CDC), Office of Global AIDS Coordinator-PEPFAR implementing office and three private companies: Becton Dickinson and Company (BD) [17]; Roche Diagnostics [18] and Siemens Healthineers [19] for \$18, \$10 and $\$ 15$ million, respectively, in shared resources. In 2012, 


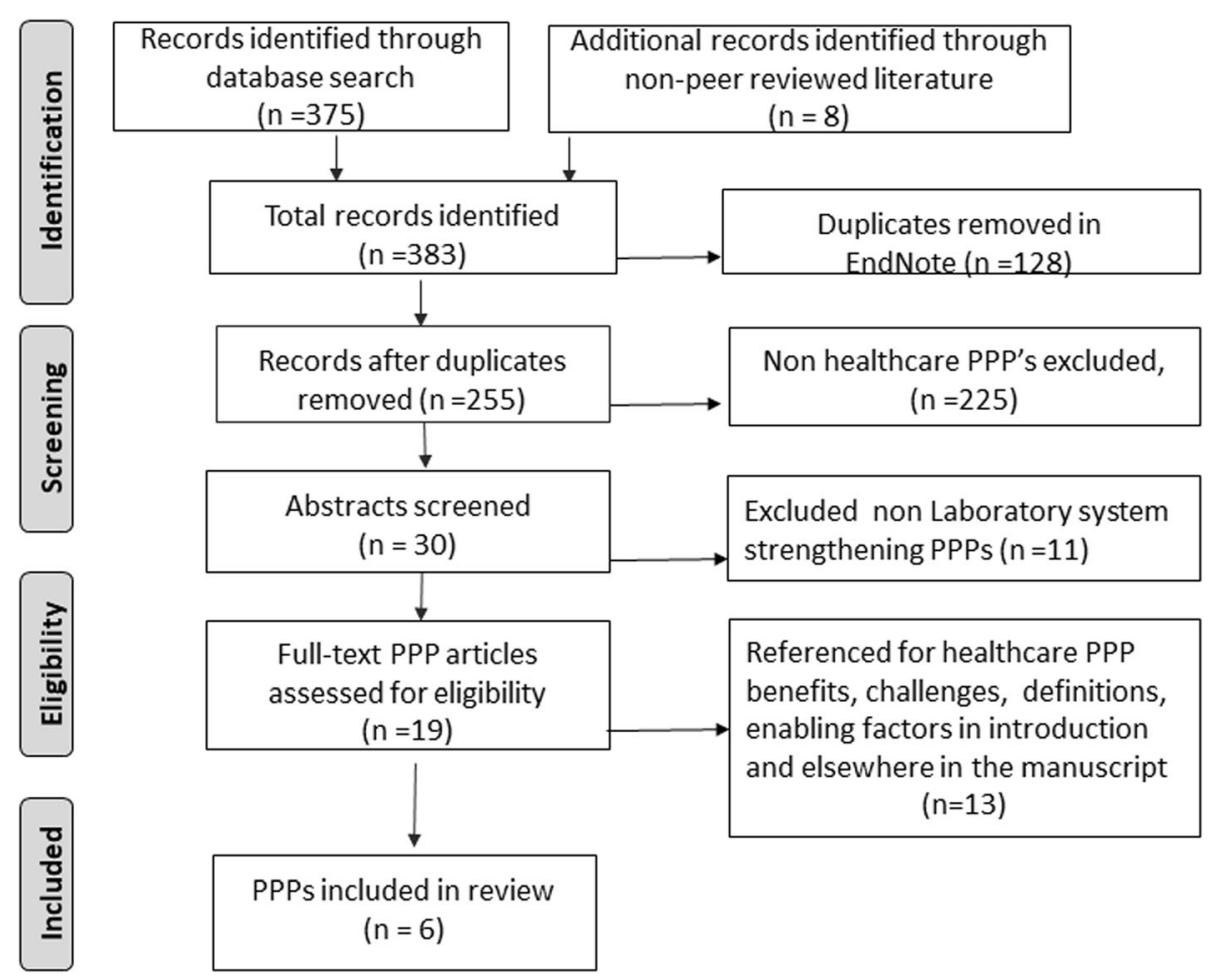

Fig. 2 PRISMA flow diagram outlining the different stages of literature review search and selection of Public-Private Partnerships (PPP) in laboratory systems strengthening

BD and PEPFAR renamed the partnership, Labs for Life, and renewed it for \$20 (2012-2017) and \$12 (20182020) million, respectively.

i). Labs for Life (L4L) strengthened access to ART by building standardized in-country capacity for specimen collection, referral and result reporting systems. With operations in Uganda, Ethiopia, Mozambique, South Africa, Kenya and India, BD deployed experts to provide in-country training (Fig. 1 and Table 1).

ii). Roche has three PPPs designated for the VL and EID programs. In 2008, only $15 \%$ of HEI in SSA were accessing EID services during the first two months of life [20]. Roche Diagnostics responded to this critical service gap with a PPP agreement with UNITAID and the Clinton HIV/AIDS Initiative (CHAI). Roche provided molecular diagnostics supplies and set up 'Turn Key Laboratories', to provide timely HIV testing for the pediatric population [20]. In 2012, Roche and PEPFAR partnered to create capacity for a welltrained laboratory cadre offering didactic courses at the Roche Scientific Campus (RSC) in Johannesburg, South Africa. In 2014, Roche signed another landmark PPP, known as the Global Access Program, which negotiated and lowered the price of VL tests in low- and middle-income countries (Fig. 1 and Table 1).

iii). Stronger Together is a five-year PPP that was signed in 2014 between PEPFAR and Siemens Healthineers, the new brand name of Siemens Healthcare company. The goal of 'Stronger Together' was to develop a competent laboratory workforce globally through a virtual education platform on social media [21].

iv). Abbott Fund, a global healthcare company, demonstrated a unique example of a locally operated PPP in Tanzania in response to the growing HIV epidemic to rapidly scale up HIV care and treatment activities. In 2001, Ministry of Health and Social Welfare (MOHSW) signed a PPP with Abbott Fund for expanded access to health care and to strengthen laboratory infrastructure [22] and system capacity (Fig. 1 and Table 1).

v). Riders for Health PPP was established 25 years ago in the United Kingdom, and continues now to be managed out of Africa [15] to address lack of access to health care among residents in remote communities in seven countries. Riders for Health managed a fleet of 1300 motor cycles and a variety of four wheeled vehicles in harsh conditions with little infrastructure to connect vital health care with 
Table 1 Summary of Public-Private Partnerships (PPPs) (2007-2017) that address barriers and strengthen laboratory systems in resource-limited settings to improve access, coverage, quality and utilization of Viral Load and Early Infant Diagnosis testing

\begin{tabular}{|c|c|c|c|c|c|c|}
\hline $\begin{array}{l}\text { Cascade } \\
\text { phase }\end{array}$ & Barrier & Country & PPP & PPP Intervention & Impact & Source \\
\hline \multirow[t]{3}{*}{$\begin{array}{l}\text { Pre- } \\
\text { analytical } \\
\text { Phase }\end{array}$} & $\begin{array}{l}\text { Poor and non- } \\
\text { standardized } \\
\text { specimen } \\
\text { collection } \\
\text { procedures. }\end{array}$ & Kenya & L4L & $\begin{array}{l}\text { - Trained } 91 \text { HCW } \\
\text { on safe phlebotomy } \\
\text { collection practices. }\end{array}$ & $\begin{array}{l}\text { - Increased } \\
\text { knowledge of } \\
\text { phlebotomists } \\
\text { by } 41 \% \text {. } \\
\text { - Integration of } \\
\text { safe phlebotomy } \\
\text { practices into } \\
\text { pre-service training. }\end{array}$ & $\begin{array}{l}\text { Kimani } \\
\text { et.al., [26] }\end{array}$ \\
\hline & $\begin{array}{l}\text { Weak supply chain } \\
\text { and unreliable } \\
\text { specimen } \\
\text { transportation } \\
\text { system. }\end{array}$ & $\begin{array}{l}\text { Gambia, } \\
\text { Kenya, } \\
\text { Lesotho, } \\
\text { Malawi, } \\
\text { Nigeria, } \\
\text { Zambia, } \\
\text { Zimbabwe. }\end{array}$ & $\begin{array}{l}\text { Riders for } \\
\text { Health }\end{array}$ & $\begin{array}{l}\text { - Accessed hard-to- } \\
\text { reach communities } \\
\text { for healthcare needs } \\
\text { by providing } \\
\text { motorcycles for } \\
\text { transportation. } \\
\text { - Trained healthcare } \\
\text { workers on } \\
\text { managing supply } \\
\text { chain distribution } \\
\text { of medicines, } \\
\text { transportation } \\
\text { of specimens } \\
\text { and return of } \\
\text { results and } \\
\text { managed emergency } \\
\text { referrals. }\end{array}$ & $\begin{array}{l}\text { - Improved access } \\
\text { to } 14.5 \text { million people } \\
\text { to healthcare. } \\
\text { - Transported } 400,000 \\
\text { specimens/year } \\
\text { between laboratory and } \\
\text { healthcare facilities. }\end{array}$ & $\begin{array}{l}\text { WHO [23, } \\
28] \\
\text { World Bank } \\
\text { [15] }\end{array}$ \\
\hline & $\begin{array}{l}\text { Weak specimen } \\
\text { transportation system. }\end{array}$ & Uganda & $\llcorner 4 \mathrm{~L}$ & $\begin{array}{l}\text { - Use of GIS to map } \\
\text { efficient sample } \\
\text { referral network. } \\
\text { - Provided standardized } \\
\text { specimen transportation } \\
\text { materials. } \\
\text { - Training of transporters } \\
\text { to safely package } \\
\text { and transport } \\
\text { specimens. }\end{array}$ & $\begin{array}{l}\text { - Ten-fold increase in } \\
\text { referrals of patients } \\
\text { sample with presum } \\
\text { ptive MDR-TB. } \\
\text { - } 94 \% \text { specimens reached } \\
\text { the national laboratory } \\
\text { within the established } \\
\text { target time of } 72 \mathrm{~h} \text {. }\end{array}$ & Joloba et al., [27] \\
\hline \multirow[t]{4}{*}{$\begin{array}{l}\text { Analytical } \\
\text { Phase }\end{array}$} & $\begin{array}{l}\text { Lack of skilled } \\
\text { workforce, modern } \\
\text { laboratory infrastructure } \\
\text { to provide timely and } \\
\text { accurate services to } \\
\text { patients. }\end{array}$ & SSA & $\begin{array}{l}\text { Global } \\
\text { Access } \\
\text { Program }\end{array}$ & $\begin{array}{l}\text { - Engaged manufacturer and } \\
\text { negotiated lower prices for } \\
\text { HIV VL and EID reagents. }\end{array}$ & $\begin{array}{l}\text { - } 300,000 \text { infants enrolled } \\
\text { into care and treatment. } \\
\text { - Provided } 900,000 \text { tests } \\
\text { for EID. } \\
\text { - - Projected anticipated } \\
\text { cost savings of } \$ 150 \\
\text { million in next } 5 \text { years. }\end{array}$ & $\begin{array}{l}\text { Roche Diagnostics } \\
{[20]}\end{array}$ \\
\hline & & SSA & $\begin{array}{l}\text { Turn Key } \\
\text { Laboratory }\end{array}$ & $\begin{array}{l}\text { - Set up'Turn Key Laboratory' } \\
\text { for access to pediatric testing. }\end{array}$ & $\begin{array}{l}\text {-900,000 tests were } \\
\text { made available. } \\
\text { - } 100 \text { laboratories in } \\
\text { SSA now routinely } \\
\text { offer PCR for EID. }\end{array}$ & $\begin{array}{l}\text { Roche Diagnostics } \\
{[20]}\end{array}$ \\
\hline & & Mozambique & $\mathrm{L} 4 \mathrm{~L}$ & $\begin{array}{l}\text { - Establishment of national } \\
\text { laboratory quality assurance } \\
\text { program to facilitate stepwise } \\
\text { quality improvement of } \\
\text { laboratory services. }\end{array}$ & $\begin{array}{l}\text { - Trained and mentorship } \\
\text { resulted in } 18 \mathrm{MOH} \\
\text { qualified auditors and } \\
28 \text { manager/quality } \\
\text { officers capacitated to } \\
\text { manage improvements } \\
\text { of laboratories and } \\
\text { steer towards accreditation. }\end{array}$ & Skaggs et al., [29] \\
\hline & & Tanzania & $\begin{array}{l}\text { Abbott } \\
\text { Fund }\end{array}$ & $\begin{array}{l}\text { - Built and modernized } 23 \\
\text { regional-level laboratories, } \\
\text { - Built outpatient center at } \\
\text { the national hospital serving } \\
1000 \text { patients/day. } \\
\text { - Provided mentorship. }\end{array}$ & $\begin{array}{l}\text { - } 10 \text { fold increase (from } \\
110,000 \text { to } 1,158,000 \text { ) } \\
\text { in test volumes in } 5 \text { years. } \\
\text { - Improved healthcare } \\
\text { services for people } \\
\text { living with HIV and other } \\
\text { chronic diseases across } \\
\text { the country. }\end{array}$ & Abbott Fund [25] \\
\hline
\end{tabular}


Table 1 Summary of Public-Private Partnerships (PPPs) (2007-2017) that address barriers and strengthen laboratory systems in resource-limited settings to improve access, coverage, quality and utilization of Viral Load and Early Infant Diagnosis testing

\begin{tabular}{|c|c|c|c|c|c|c|}
\hline $\begin{array}{l}\text { Cascade } \\
\text { phase }\end{array}$ & Barrier & Country & PPP & PPP Intervention & Impact & Source \\
\hline \multirow[t]{2}{*}{$\begin{array}{l}\text { Post - } \\
\text { analytical } \\
\text { phase }\end{array}$} & \multirow[t]{2}{*}{$\begin{array}{l}\text { Delayed and } \\
\text { inconsistent } \\
\text { delivery of VL } \\
\text { and EID test } \\
\text { results to } \\
\text { patients. }\end{array}$} & Ethiopia & L4L & $\begin{array}{l}\text { - Used GIS to map and } \\
\text { network } 554 \text { clinic facilities } \\
\text { to laboratories testing for VL, } \\
\text { EID, CD4 and hematology. } \\
\text { - Procured } 400 \text { standard } \\
\text { specimen transportation } \\
\text { containers. } \\
\text { - Trained } 586 \text { and } 81 \\
\text { laboratory and } \\
\text { postal workers, } \\
\text { respectively. }\end{array}$ & $\begin{array}{l}\text { - } 50 \% \text { reduction in } \\
\text { TAT (from } \\
\text { specimen collection } \\
\text { to reporting } \\
\text { results) for ART } \\
\text { patients (10 to } 5 \\
\text { days). } \\
\text { - Standardized training } \\
\text { module used for } \\
\text { training in all } \\
\text { the regions } \\
\text { - } 62 \% \text { in cost savings for } \\
\text { transporting EID } \\
\text { specimens. } \\
\text { - Reduced TAT from } \\
1 \text { to } 2 \text { months } \\
\text { to } 5-10 \text { days. }\end{array}$ & $\begin{array}{l}\text { Kebede et al., [32] } \\
\text { Kiyaga et al. [6] }\end{array}$ \\
\hline & & $\begin{array}{l}\text { Kenya, } \\
\text { Tanzania } \\
\text { and Rwanda }\end{array}$ & $\begin{array}{l}\text { Phones } \\
\text { for Health }\end{array}$ & $\begin{array}{l}\text { - Allowed input } \\
\text { of health data } \\
\text { and transfer to } \\
\text { central database. } \\
\text { - Enabled ordering } \\
\text { medicines, } \\
\text { sending alerts and } \\
\text { download of guidelines. } \\
\text { - Enabled access to } \\
\text { training materials. } \\
\text { - Facilitated transmission } \\
\text { of results to SMS } \\
\text { printers. }\end{array}$ & $\begin{array}{l}\text { - Improved access } \\
\text { to knowledge and } \\
\text { information of 50,000 } \\
\text { community health workers. } \\
\text { - Reduced TAT } \\
\text { for results delivery } \\
\text { - Effective monitoring } \\
\text { of mother-to-child } \\
\text { transmission through } \\
\text { EID systems rolled } \\
\text { out to } 63 \text { sites } \\
\text { nationally. }\end{array}$ & $\begin{array}{l}\text { UNAIDS [25], } \\
\text { Fogarty [24] }\end{array}$ \\
\hline
\end{tabular}

a = Labs for Life;

Abbreviations: $L 4 L$ Labs for Life, HCW healthcare workers, GIS geographic information system, MDR-TB multidrug resistant tuberculosis, $P C R$ polymerase chain reaction, SSA sub Saharan Africa, VL viral load, EID early infant diagnosis, ART antiretroviral therapy, MOH ministry of health, TAT turnaround time, WHO World Health Organization, CD4 cluster of differentiation 4, SMS short message service

rural areas hitherto unreachable except on foot [23].

vi). Phones for Health PPP was initiated in 2007 with operations in countries including Kenya, Tanzania, and Rwanda, leveraging over \$3 million annually [24]. Utilizing mobile phone technologies or $\mathrm{mHealth}$ as tools and platforms for health research and healthcare delivery [25]. It is a PPP between the health care software provider Voxiva, the phone producer Motorola, the telecom company MTN, the GSMA Development Fund, PEPFAR, CDC Foundation and Accenture Development Partnerships.

\section{Impact of PPPs addressing barriers to scale up HIV viral load and early infant diagnostic testing}

Taken together, the collective contributions of the six eligible PPPs have impacted a cost savings of $62 \%$, increased access to 14.5 million patients to healthcare, transported 400,000 specimens/year, tested 300,000 additional HEI, reduced turnaround time of reporting results by $50 \%$. The specific contributions of the six PPPs within the pre-analytical, analytical and post analytical phases of the VL and EID cascade are highlighted below (Fig. 1 and Table 1).

A. Pre-analytical phase

i). Demand creation for testing: In 2014, when Global Access Program lowered the price of VL testing by $40 \%$ thereby increasing its affordability and availability, it was projected that this PPP will save more than $\$ 150$ million in costs over the next 5 years [20].

ii). Specimen collection and processing: L4L PPP made significant progress in improving blood draw practices by developing and institutionalized a curriculum for phlebotomists to standardize safe blood-drawing procedures in Kenya. Following the initial curriculum training, the average knowledge increase was $41 \%$ for phlebotomists [26], which they went on to apply in their practices. 
iii). Specimen transport system: In 2007, Uganda's effort to control the spread of the deadly Multidrug-Resistant Tuberculosis (MDR-TB) was severely limited by weak laboratory network coupled with inadequate specimen referral and result reporting system. L4L PPP collaborated with Ugandan Ministry of Health (MOH), CDC and local partners to use geographic information system (GIS) technology to map and strengthen a national specimen referral system [27]. This resulted in $94 \%$ of specimens reaching the national laboratory within the established target time of $72 \mathrm{~h}$. This model later served as the cornerstone for the EID specimen transportation and result reporting system and generated a cost savings of $62 \%$ and reduced average turnaround time from 1 to 2 months to 510 days [6]. Riders for Health transported 400,000 blood and sputum samples between laboratories and health centers every year and improved access to healthcare for 14.5 million people in Gambia, Kenya, Lesotho, Malawi, Nigeria, Zambia, Zimbabwe [15, 28].

B. Analytical phase

i). Laboratory testing: Roche's PPP for "Turn Key Laboratory" introduced a paradigm shift for expanding laboratory services for pediatric HIV patients resulting in 900,000 tests being made available, an increase of 300,000 infants enrolled into care and treatment, and Polymerase Chain Reaction (PCR) testing being routinely provided in more than 100 laboratories [20].

ii). L4L PPP has also played a significant role in strengthening Continuous Quality Improvement (CQI) of laboratories in several SSA countries including Mozambique, Kenya, Ethiopia, India. In a joint collaboration, L4L helped $\mathrm{MOH}$ Mozambique program by providing training and mentorship that resulted in $18 \mathrm{MOH}$ qualified auditors and 28 manager/quality officers capacitated to establish a national laboratory quality assurance program [29].

iii). In collaboration with CDC Tanzania and partners such as Design 4 Others and the Association of Public Health Laboratories, the Abbott Fund's PPP contributed $\$ 10$ million to building and strengthening a network of 23 regional-level laboratories in Tanzania [25]. These laboratories provided support for 120 district hospital laboratories resulting in improved healthcare services.
Abbott Fund provided mentoring, technical support, and expertise in the areas of construction, engineering, infection control, waste management, information technology, and laboratory management [30]. This PPP also built a modern outpatient center at the Muhimbili National Hospital serving over 1000 patients a day for HIV and non-communicable ailments and the system strengthening efforts increased by 10 fold laboratory tests volumes [31].

C. Post analytical phase

i). Result reporting and interpretation by clinicians: From 2010 to 2012, L4L, MOH and CDC partnership in Ethiopia reduced the turnaround time of laboratory patient results by $50 \%$ from 10 to 5 days [32] in 554 (59\%) of the 944 districts. The program has demonstrated sustainable expansion covering $800(85 \%)$ of the 944 districts as of 2017 and transports specimens for CD4, EID, chemistry, hematology and TB tests, independent of the PPP.

ii). Phones for Health PPP enabled health workers to input health data and transfer them to a central database, order medicines, send alerts, download guidelines, and access training materials. In Rwanda, it empowered practitioners to monitor antiretroviral drug stocks in real time, and accelerated the return of CD4 and viral load test results to remote facilities. In September 2012, 252 of the 457 health facilities were using the electronic system ( $>50 \%$ of coverage) [33]. Kenya and other countries have used the mhealth technology to transmit laboratory results to mobile phones which are sent to SMS printers in referring clinics to utilize for patient management $[24,25,34-36]$.

\section{Discussions}

Opportunities for PPPs to scale up HIV viral load and early infant diagnostic testing

Globally, as of 2016, 70\% of people living with HIV (PLHIV) were diagnosed, $77 \%$ of those were on ART, and $82 \%$ of those were virally suppressed [37]. This finding highlights the need for additional synergistic partnerships to close the gap in HIV testing, treatment, and viral suppression. Since 2006, the U.S. has been engaged in nearly 300 partnerships, which have yielded nearly $\$ 400$ million in private sector investment and \$335 million in funding from PEPFAR [38]. More PPP are needed 
with a focus to strengthen laboratory systems and networks. There are still challenges, for instance, access to testing, return of laboratory test results to patients, ensuring quality of testing, develop a cadre of trained workforce, and present opportunities for collaborations to increase efficiencies. PPPs can play a key role in addressing some of these challenges.

a). Uptake of VL and EID test results: To close the knowledge gap of clinicians (e.g., nurses, midwives, clinical officers, medical doctors) for the uptake of viral load test results [39], members of African Regional Collaborative for Laboratory Technologists collaborated with Roche-PEPFAR PPP and provided VL training to nurse leaders from 17 countries in SSA. The training emphasized the role of nurses in initiating request for VL testing and utilizing VL test results for patient management in ART clinics [40].

b). Safe and standardized specimen collection process: Phlebotomy-related errors account for > $60 \%$ of errors in the pre-analytical phase [41] and can lead to delayed or incorrect results, with unjustifiable costs to patient. Roche-PEPFAR PPP collaborated with the US CDC to develop an online training tool to standardize specimen collection procedures using an alternate specimen type - dried blood spots (DBS), to improve access to viral load testing. The training is accessible at the African Society for Laboratory Medicine (ASLM) portal in English, French and Portuguese [42].

c). Quality assured test results to clients:

Strengthening the tiered laboratory network in a country to expand and ensure access to reliable, high-quality VL and EID testing services is critical [39]. US CDC developed a CQI program and Roche-PEPFAR PPP continue to offer the CQI program in its campus in Johannesburg. Average pretest scores in five courses for 94 students from 22 countries rose from 12 to $88 \%$ (personal communication, facilitator Anna Murphy, affiliation ASLM). To develop a sustainable, cost-effective solution for wider dissemination, Stronger Together PPP replicated the two week long didactic curriculum into an e-library of 48 training videos, available free of cost through an innovative e-platform [43]. This approach has caught the interest of $\mathrm{MOH}$ in several African countries and can also be used to deploy training materials in any area including VL and EID.

d). Specimen transport and result reporting system: Innovative strategies such as unmanned aerial vehicles to pick up specimens and deliver results within Switzerland (Matternet company) [44] and in Rwanda and Tanzania (Zipline company) [45] are examples of technology for use in improving laboratory-clinic interface. These innovations could be leveraged to improve delivery of VL and EID results in similar contexts.

Other unmet needs in the VL cascade represent opportunities for new partnerships. The needs are inadequate and competent workforce, unsafe disposal of hazardous waste materials generated due to increased volume of testing, equipment maintenance, limited data management options to improve laboratory-clinic interface (Fig. 1).

\section{Benefits of PPP to private and public sector}

PPPs provided an avenue for private entities to gain access and improved understanding of government's policies and strategies, which can increase market knowledge and awareness of national priorities. By engaging in PPPs, the private sector can also benefit the local workforce by providing increased access to resources; introducing new goods and services; sharing product/service risks and investments [7], identifying and increasing local expertise; institutionalizing interventions; and build sustainable laboratory networks with regard to public-supported laboratories [32]. From the public sector perspective, effective PPPs provide additional capabilities, flexibility, skills, resources and funding, which enhance their ability to respond to the demands for increased services or scale-up programs of national importance. Furthermore, at the country-level, PPP's collaboration can empower countries to mobilize funds and direct them towards highest priority activities; facilitate research and development; and improve affordable healthcare interventions [12].

\section{Strengths and limitations}

This review successfully identified PPPs that have contributed to achieving UNAIDS 90-90-90 treatment goals. While most of the PPP were international, we observed the important role played by local indigenous PPP and further highlighting the important contribution of PPPs. We are cognizant of the small number of published studies highlighting PPP in laboratory system strengthening. Nonetheless, their impact remains unquestionable and underscore the need for more laboratory systems and service delivery focused PPP.

\section{Conclusions}

Clearly PPP plays a critical role towards achieving the UNAIDS 90-90-90 targets. Despite the growing emphasis on engaging the private sector as a critical partner to address health care systems, PPPs that strengthen laboratories, the cornerstone of public health programs remain largely untapped. Increased partnerships between 
public sector and private companies are needed to synergistically address the challenges of achieving universal HIV testing, VL and EID scale up. Opportunities for new local and global PPPs should be harnessed for a standardized and sustained scale up of VL and EID to reach the 90-90-90 goals.

\section{Acknowledgements}

The authors would like to thank Joanna M. Taliano, librarian at Center for Disease Control and Prevention, Atlanta, USA for helping in the literature search. The authors are indebted to Chin-Yih Ou, retired senior officer China CDC for critically reviewing the manuscript. Authors would also like to acknowledge input of Ellen Sampson, Director, Global Marketing at Siemens Healthineers and William Magagna, Vice President Virtual Education Solutions at Siemens Healthineers.

\section{Funding}

The President's Emergency Plan for AIDS Relief (PEPFAR) supported staff who designed the study; collected, analyzed, and interpreted the findings; and wrote and reviewed the manuscript.

\section{Availability of data and materials}

Data used for this systematic review are available through peer-reviewed materials cited in the manuscript and can be freely accessed online. The data is also available upon request from the corresponding authors.

\section{Declarations}

The findings and conclusions in this report are those of the author(s) and do not necessarily reflect the views of the Centers for Disease Control and Prevention.

\section{Authors' contributions}

RS, PNF, AK, JNN conceived and designed the study; RS, PNF, AK analyzed the data; RS, PNF, AK wrote the paper; RS, PNF, YK, RB, SZ, CM, RG, HA, PLR, $A K$, JNN interpreted the results, critically reviewed and revised the manuscript, and approved the final manuscript.

\section{Ethics approval and consent to participate}

Not applicable; literature review-based research and not involving human subjects or human material.

\section{Consent for publication}

Not applicable

\section{Competing interests}

The authors declare that they have no competing interests.

\section{Publisher's Note}

Springer Nature remains neutral with regard to jurisdictional claims in published maps and institutional affiliations.

\section{Author details}

'International Laboratory Branch, Division of Global HIV/AIDS, Center for Global Health, Centers for Disease Control and Prevention, 1600 Clifton Road NE, Atlanta, GA 30333, USA. ${ }^{2}$ Centers for Disease Control and Prevention, Addis Ababa, Ethiopia. ${ }^{3}$ Roche Diagnostics, Johannesburg, South Africa. ${ }^{4}$ Centers for Disease Control and Prevention, Kigali, Rwanda. ${ }^{5}$ Becton Dickinson and Company, Trenton, NJ, USA. ${ }^{6}$ Africa Centres for Disease Control and Prevention, Addis Ababa, Ethiopia.

Received: 20 August 2018 Accepted: 20 November 2018

Published online: 18 January 2019

\section{References}

1. UNAIDS. 90-90-90: An ambitious treatment target to help end the AIDS epidemic. Geneva: Switzerland: Joint United Nations Programme on HIV/ AIDS (UNAIDS); 2014. p. 33

2. PEPFAR. PEPFAR 3.0 Controlling the Epidemic: Delivering on the Promise of an AIDS-free Generation 2014.
3. Justman J, Koblavi Deme S, Tanuri A, Goldberg A, Gonzalez L, Gwynn C. Developing laboratory systems and infrastructure for HIV scale-up: a tool for health systems strengthening in resource-limited settings. J Acquir Immune Defic Syndr. 2009;52(Suppl 1):S30-3.

4. Fonjungo PN, Alemnji GA, Kebede $Y$, et al. Combatting global infectious diseases: a network effect of specimen referral systems. Clin Infect Dis. 2017;64:796-803.

5. Lecher S, Williams J, Fonjungo PN, et al. Progress with scale-up of HIV viral load monitoring — seven sub-Saharan African countries, January 2015-June 2016. MMWR Morb Mortal Wkly Rep. 2016;65:1332-5.

6. Kiyaga C, Sendagire $H$, Joseph $E$, et al. Uganda's New National Laboratory Sample Transport System: A Successful Model for Improving Access to Diagnostic Services for Early Infant HIV Diagnosis and Other Programs. PloS One. 2013; 8(11): e78609.

7. McKinsey and Company. Public-Private Partnerships Harnessing the private sector's unique ability to enhance social impact, 2009.

8. Peeling RW, Boeras DI, Nkengasong JN. Re-imagining the future of diagnosis of neglected tropical diseases. Comput Struct Biotechnol J. 2017;15:271-4.

9. Fonjungo PN, Osmanov S, Kuritsky J, et al. Ensuring quality: a key consideration in scaling-up HIV-related point-of-care testing programs. Aids. 2016;30:1317-23.

10. Asuquo AE, Pokam BD, Ibeneme E, Ekpereonne E, Obot V, Asuquo PN. A public-private partnership to reduce tuberculosis burden in Akwa Ibom state, Nigeria. Int J Mycobacteriology. 2015;4:143-50.

11. Vian T, Richards SC, McCoy K, Connelly P, Feeley F. Public-private partnerships to build human capacity in low income countries: findings from the Pfizer program. Human Resour Health. 2007;5:8.

12. Kostyak L, Shaw DM, Elger B, Annaheim B. A means of improving public health in low- and middle-income countries? Benefits and challenges of international publice private partnerships. Public Health. 2017;149:120-9.

13. Sulzbach S, De S, Wang W. The private sector role in HIV/AIDS in the context of an expanded global response: expenditure trends in five sub-Saharan African countries. Health Policy Plan. 2011;26:i72-84.

14. White J, Callahan S, Lint S, Li Helen, Yemaneberhan A. Engaging private health providers to extend the global availability of PMTCT services Available at: http://www.popline.org/node/654988. Accessed Dec 2017.

15. Bank W. Public private partnerships for health: PPPs are Here and growing. In: Africa health Forum Finance and capacity for results; 2013.

16. PEPFAR. Public Private Partnerships. Available at: https://www.pepfar.gov/ partnerships/ppp/. Accessed Jan 2018

17. Dickinson BC. BD and PEPFAR launch labs for life to strengthen Laboratories in Regions Heavily Burdened by disease; 2012.

18. Roche. Roche and the US President's Emergency Plan for AIDS Relief (PEPFAR) partner to strengthen laboratories medicine training and knowledge on the African continent. Available at: http://www.roche.com/ media/store/releases/med-cor-2012-12-04.htm. Accessed Feb 2018.

19. Siemens Healthcare. New Public-Private Partnership Uses e-Learning to Fight HIV/AIDS Available at: https://www.businesswire.com/news/home/ 20140922005881/en/Public-Private-Partnership-E-Learning-Fight-HIVAIDS\#. VCCDs42x4mh. Accessed March 2018

20. Roche Diagnostics Commitment and Care Across the Globe Making a world of difference in HIV/AIDS and TB. Available at: https://www.roche com/dam/jcr:87619bc4-5054-46d1-a028-7a798de807b9/en/sustdiagnostics-access.pdf. Accessed March 2018.

21. Healthineers S. PEPFAR Rapid HIV Testing Continuous Quality Improvement (RT-CQI). Available at: https://pep.siemens-info.com/en-us/ pepfar-hiv-rtcqi. Accessed 11th June 2018.

22. Massambu C, Mwangi C. The Tanzania experience: clinical laboratory testing harmonization and equipment standardization at different levels of a tiered health laboratory system. Am J Clin Pathol. 2009;131:861-6.

23. Wharton Univ of Penn. Riders for Health. Available at: https:// lipmanfamilyprize.wharton.upenn.edu/2015-finalist-riders-for-health/. Accessed Feb 2018

24. Fogarty International Center. Mobile Health (mHealth) information and Resources Glob Health Matters. Vol. 8. National Institute for Health: Fogarty, 2009

25. UNAIDS. HIV-related Public-Private Partnerships and Health Systems Strengthening, 2009

26. Kimani $D$, Kamau $R$, Gadde $R$, et al. Findings of phlebotomy practices in Kenya in 2010: need for action. (Special Issue: Public-private partnership and strengthening laboratory systems in Africa.). J Infect Dis. 2016:213: S53-S8. 
27. Joloba M, Mwangi $\mathrm{C}$, Alexander $\mathrm{H}$, et al. Strengthening the tuberculosis specimen referral network in Uganda: the role of public-private partnerships. J Infect Dis. 2016;213:41-6.

28. WHO for Special Programme for Research and Training in Tropical Diseases T. Special Programme for Research and Training in Tropical Diseases, TDR. Available at: http://www.who.int/tdr/news/2016/riders-for-health/en/. Accessed Feb 2018.

29. Skaggs B, Pinto I, Masamha J, Turgeon D, Gudo ES. Implementing laboratory quality Management Systems in Mozambique: the Becton Dickinson-US President's emergency plan for AIDS relief public-private partnership initiative. J Infect Dis. 2016;213:S47-52.

30. Abbott. Improving Access to Healthcare in Tanzania. Available at: https:// www.abbott.com/responsibility/social-impact/access-to-healthcare/articles/ healthcare-access-tanzania.html. Accessed December 2018

31. Abbott and Abbott Fund. Elevating Healthcare In Tanzania. Available at: https://www.abbott.com/responsibility/social-impact/access-to-healthcare/ healthcare-in-tanzania.html-. Accessed Feb 2018.

32. Kebede Y, Fonjungo PN, Tibesso G, et al. Improved specimen-referral system and increased access to quality Laboratory Services in Ethiopia: the role of the public-private partnership. J Infect Dis. 2016;213:S59-64.

33. Center for Health Market Innovations. TRACnet. Available at: https:// healthmarketinnovations.org/programs/search/tracnet. Accessed Feb 2018.

34. mHealth Kenya Public Private Partnership. Leveraging technology to improve health care outcomes. Available at: https://mhealthkenya.org/. Accessed Feb 2018.

35. Kizito K, Adeline K, Baptiste KJ, et al. TRACnet: a National Phone-based and web-based tool for the timely integrated disease surveillance and response in Rwanda. Online J Public Health Inform. 2013;5:202.

36. World Health Organization. Mobile health: transforming the face of health service delivery in the African Region. Available at: http://www.aho.afro.who. int/en/blog/2015/03/10/mobile-health-transforming-face-health-servicedelivery-african-region. Accessed Aug 2017.

37. UNAIDS. Ending AIDS, progress towards the $90-90-90$ targets, vol. 2017. p. 32

38. Goosby E, Zygocki R I. Public-Private Partnerships Are Vital to Creating an AIDS-Free Generation. Available at: http://www.huffingtonpost.com/ ambassador-eric-goosby-md/publicprivate-partnership_3_b_3719564.html. Accessed April 2018

39. Trevor P, Ellenberger Dennis KA, et al. Early antiretroviral therapy initiation: access and equity of viral load testing for HIV treatment monitoring. Lancet Infect Dis. 2017;17:e26-e9.

40. Riley PL, Rurangirwa J, Fowler L, Ellenberger D, Raizes E, Nkengasong NJ. Nursing and midwifery knowledge, attitudes, and practices towards viral load testing for managing HIV-infected patients in east, central and southern Africa. J Midwifery Womens Health. 2016;61:661-2.

41. Lima-Oliveira G, Guidi GC, Salvagno GL, et al. Is phlebotomy part of the dark side in the clinical laboratory struggle for quality? Lab Med. 2012;43:172-6.

42. ASLM. HIV Viral Load Scale up Tools. Available at: http://www.aslm.org/hivviral-load-testing/hiv-viral-load-scale-tools/. Accessed 11th June 2018.

43. Healthineers S. PEPFAR Quality Control and Method Validation. Available at: https://pep.siemens-info.com/en-us/pepfar-qc-workshop. Accessed June 11 2018.

44. Stewart J. Switzerland's Getting a Delivery Network for Blood-Toting Drones Available at: https://www.wired.com/story/switzerlands-getting-a-deliverynetwork-for-blood-toting-drones/. Accessed Feb 2018.

45. Forbes. Zipline Is Launching The World's Largest Drone Delivery Network In Tanzania. Available at: https://www.forbes.com/sites/leifwalcutt/2017/08/24/ zipline-is-launching-the-worlds-largest-drone-delivery-network-in-tanzania/ \#11071ef3293b. Accessed Mar 2018

\section{Ready to submit your research? Choose BMC and benefit from:}

- fast, convenient online submission

- thorough peer review by experienced researchers in your field

- rapid publication on acceptance

- support for research data, including large and complex data types

- gold Open Access which fosters wider collaboration and increased citations

- maximum visibility for your research: over $100 \mathrm{M}$ website views per year

At $\mathrm{BMC}$, research is always in progress.

Learn more biomedcentral.com/submissions 